\title{
THE NEED FOR A PARADIGM SHIFT IN FINANCE: SUSTAINABLE CORPORATE FINANCE
}

\author{
AGÂRBICEANU Simona Marcela ${ }^{1}$ and PĂUN Tatiana ${ }^{2}$ \\ Lucian Blaga University of Sibiu, Romania, Faculty of Economics, simona.agarbiceanu@ulbsibiu.ro \\ University of Craiova, Romania, Faculty of Economics and Business Administration, tatianazamfiroiu@yahoo.fr
}

\begin{abstract}
Under current global conditions, finance may play a critical role in allocating investment to sustainable enterprises and projects, thereby hastening the transition to a low-carbon circular economy. Finance promotes risk assessment and, as a result, can aid in addressing the inherent ambiguity surrounding environmental concerns such as the impact of carbon emissions on climate change. In recent decades, thinking about sustainable finance has progressed through several stages, with the emphasis steadily changing from short-term profit to long-term value creation. This study seeks to conduct an examination of the concept and premises of sustainable corporate finance based on literature research, with the goal of bringing arguments to the need to shift the financial paradigm. This emerging perspective emphasizes that, while profit creation and maximization are important, firms must also seek other goals that have an impact on society, such as those connected to sustainable development. The integration of environmental, social, and governance components into financial decision-making processes is referred to as sustainable finance. Recent developments highlight the importance of businesses' commitment to responsible behavior in transforming the company into a truly sustainable enterprise that adds value to the business, society, and the environment.
\end{abstract}

KEY WORDS: sustainability, sustainable corporate finance

\section{INTRODUCTION}

The core principle of sustainability is that an explicit link should be established between current and future generations. The notion was first introduced in environmental interpretation during United Nations conferences in the 1970s and 1980s. Sustainability as a phenomenon has quickly infiltrated both the economic and financial literatures, becoming a prominent academic topic of study (Kates et al., 2001; Dresner, 2012; Ahi et al., 2018; Hussain et al., 2018; Tseng et al., 2018). How to adapt to globalized international norms, future difficulties, and new models in technologies and products are all vital components of sustainable development.

In the case of corporate activity, one of the most commonly used words is "sustainability." Sustainability is a big concern for businesses of all sizes in an effort to save resources for future generations (James, 2014). Corporate sustainability can be viewed as a new paradigm in the field of corporate governance, offering an alternative to the traditional model of profit creation and maximization as the primary purpose of the organization. This emerging perspective emphasizes that, while profit creation and maximization are important, firms must also seek other goals that have an impact on society, such as those connected to sustainable development. The sustainability approach offers a framework for value creation that relates to both achieving sufficient earnings for the organization and addressing the needs of a varied range of stakeholders (Lopez et al., 2007). Sustainability considers not only the interests of investors and shareholders, but also the responsibilities of stakeholders who are affected or tied to the business in some way. Any definition of sustainability should include intergenerational justice because it involves not just an efficient use of resources, but also a fair distribution of those resources among current, present, and future generations.

Corporate finance that is environmentally friendly and sustainable is more vital now than it has ever been. Financial markets, political actors, and the general public are all paying increased attention to them. Their goal is to use environmental, social, and governance (ESG) principles when making financial decisions and constructing financial services, thereby benefiting the entire society rather than just investors. Green and sustainable finance, which extends beyond finance's main job of fueling the economy, is being questioned by academics and practitioners.

To answer issues about green and sustainable finance, a new financial methodology is required. This paper compares and contrasts the existing ideas of traditional finance and behavioral finance with the new idea of sustainable corporate finance. Extra-financial considerations must be factored into financial decision-making processes in financial markets, corporate finance, and corporate governance. The study suggests that, rather than the current one-dimensional risk and return focus, finance as a discipline requires a comprehensive perspective.

The reminder of this article is structured as follows: Section 2 includes a review of the literature that defines key terms such sustainability, corporate sustainability, corporate social responsibility, and corporate sustainable finance, as well as a brief summary of the findings of causality studies between sustainability and performance. The final section makes the case for the need for a new paradigm of sustainable corporate finance. The study's conclusions are summarized in the final section of the article.

\section{LITERATURE REVIEW}

\subsection{Sustainability as a concept, from global to corporate}

There is scientific agreement on the relevance of sustainability at the organizational level (Salvioni et al., 2016; Smigielska, 2018; van Marrewijk \& Werre, 2003; Linnenluecke \& Griffiths, 2010; Boros \& Fogarassy, 2019; Ababneh \& Aga, 2019; Nielsen, 2018), but also at national and global levels (Clayton \& Radcliffe, 2015; Drexhage \& Murphy, 2015; Liu et al., 2015). As a result, sustainability has become a critical component of the 
strategies of individuals, businesses, and governments. The World Commission on Environment and Development (WCED) published the report Our Common Future in 1987, which popularized the concept of sustainability on a worldwide scale. WCED linked sustainability to environmental integrity and social equity, but also to corporations and economic prosperity, by coining the term sustainable development, defined as "development that meets the needs of the present without jeopardizing future generations' ability to meet their own needs." A variety of later definitions of organizational sustainability, often known as corporate sustainability, evolved as a result of influences from strategy and management literature.

Sustainable development is a problem that we all care about; citizens, corporations, and governments must work together to make sustainable consumption a societal aim (Malovics et al., 2008).

There are various definitions of sustainability. According to Lubin and Esty (2010), sustainability is proven by the company's social responsibility, which must be manifested and supported by socially responsible investments, the organization aiming to meet complex performance criteria, including non-financial criteria that refer to environmental management and solving social problems.

The global economy requires organizations to reassess their economic, social, and environmental goals and to achieve business model transformation faster, more frequently, and more widely than in the past, in order to demonstrate the ability to develop sustainable business through clearly expressed and transparent strategies (Doz \& Kosonen, 2010).

Corporate sustainability refers to the extension of the notion of sustainable development from the level of society to the level of organizations. There is currently no widely agreed definition of business sustainability in the literature.

Corporate sustainability can be defined as the adoption of business strategies and those activities that meet the current needs of the organization and stakeholders, while protecting the human and natural resources that will be needed in the future (International Institute for Sustainable Development, 1992), meeting the direct and indirect needs of the firm and stakeholders (shareholders) (van Marrewijk, 2003). The definitions of corporate sustainability vary on the degree to which they classify it as either mainly ecological concern (WCED, 1987) or as social responsibility of an organization (Shrivastava, 1995), or broaden the concept of corporate sustainability to integrate corporate economic activities with organizational concern about the natural and the social environment (Carroll, 1999; Dunphy et al., 2003; Dyllick \& Hockerts, 2002).

Sustainable development, corporate social responsibility (CSR), and corporate citizenship are all related to business sustainability. Organizations are not only expected, but it is also in their best interests to be so. In order to maximize overall value captured, sustainable value creation necessitates systems thinking. New business prospects and models are emerging as a result of both this sustainable drive and technical advancement, as well as societal and mentality change (Oprean-Stan, Oncioiu, Iuga, Stan, 2020). The ultimate goal is for the organization to develop and perform well.

Depending on the business setting, corporate sustainability can have a variety of implications. Corporate sustainability is a strategy aimed at creating long-term stakeholder value through the implementation of a corporate strategy that integrates social, environmental, and economic challenges. Because it is preventative rather than reactive, sustainable management contributes to a company's long-term viability. The goal is to restructure organizations so that they contribute to the long-term development of the economy and society within the constraints of the environment. Leaders, managers, and entrepreneurs are pushed to contribute to individual, organizational, and societal development. The tactics developed are meant to promote organizational longevity, transparency, and proper personnel development. It can take a variety of forms, such as investing in fair-trade items, decreasing packaging materials, and assuring humane working conditions at supplier facilities.

Business sustainability objectives are becoming more significant for both enterprises and stakeholders. Organizations must try to design long-term successful strategies in accordance with stakeholder requirements in order to achieve sustainable business, paying equal weight to human resources, the balance of the society in which they operate, and the environment (Lepineux et al., 2010).

Inclusion of social responsibility objectives in organizational strategy is an important requirement in establishing sustainable business, but not only for defining a favorable image, acquiring a competitive advantage, and boosting operational efficiency. According to Dey and Sircar (2012), corporate social responsibility initiatives must be integrated and assimilated by the firm in order for them to be placed at the core of the organization. As a result, organizations must use their skills, resources, and management competence to advance societal progress (Beschorner, 2013; Porter \& Kramer, 2011).

Businesses operate in a global context influenced by the past, present, and future. As a result, because it addresses both the future and the present, a short-term approach to sustainability is no longer acceptable (Oprean-Stan, Stan, Bratian, 2020). As a result, the notion of sustainability considers not just profit, but also the long-term viability of the business. The new framework for business sustainability is based on three pillars: economic integrity, social equity and value, and environmental integrity. It is obvious that the combination of these variables will assist businesses in becoming more sustainable by meeting long-term development goals, enhancing efficiency, and maximizing shareholder value. The underlying assumption of corporate sustainability is that businesses should completely integrate social and environmental goals with financial goals, and explain their welfare actions to a broader variety of stakeholders via an accountability and reporting framework.

Recent advances suggest that an organization's commitment to responsible behavior can result in the transformation of the corporation into a truly sustainable firm that adds value to the business, society, and the environment. As a result, increasing economic performance, operational efficiency, higher quality, innovation, and competitiveness are all tied to the concept of sustainability and corporate responsibility.

Corporate social responsibility is more than just a cost, a limitation, or a philanthropic deed. This is a source of potential, innovation, and competitive advantage (Porter \& Kramer, 2006).

\subsection{Previous research findings on the relationship between sustainability and performance}

Prior research has, both theoretically and empirically, tried to establish the relationship between corporate sustainability performance and financial performance. However, so far the results have been either inconclusive or inconsistent. As a result, 
roughly dividing previous research into two main camps supporting either a positive or negative relationship.

According to many studies, sustainability has a favorable impact on long-term financial performance, return on investment, and ultimately leads to sufficient earnings for the organization. Companies that are not interested in environmental responsibility may see their share prices fall if their investors are realistic in analyzing the company's future value based on the current status of environmental responsibility (Ngwakwe, 2008). Furthermore, corporations who harm the environment may see a slow decline in sales, jeopardizing their future solvency. As a result, social responsibility or sustainability initiatives can improve a company's financial success (Rahmanti, 2012).

The initiatives of firms toward sustainable development and the disclosure of non-financial information have both benefits and drawbacks. Non-financial information disclosure and reporting can have both a beneficial and negative impact on financial performance, depending on the stronger effect. Furthermore, whether a beneficial impact is disclosed is dependent on the features of the country as a whole, the specific industry or market in which the company operates, and the firm's features. In practice, research have found both the existence and absence of a favorable link (Borodin, 2019).

A substantial number of studies have been undertaken to date, utilizing various approaches and samples, that have indicated the presence of a beneficial influence of non-financial report release on financial performance (Caesaria \& Basuki, 2017). Alshehhi et al. (2018) did a thorough review of the literature on the influence of reporting corporate sustainability on the financial performance of the organization. The authors examined 132 papers published in peer-reviewed journals and determined that $78 \%$ of articles reveal a positive association between a company's sustainability and financial performance. Only $22 \%$ of the evaluated publications show a negative, mixed, or no significant association between the company's sustainability and financial performance. Ameer and Othman (2012) investigate the top 100 sustainable enterprises and discover a positive link between sustainability reporting and financial performance.

The presentation of economic, environmental, and social issues in the sustainability report had a substantial impact on the company's market performance. These three components reflect their company's contribution to global and local economic development, as well as their care for the environment and social commitment to the community, and will boost the company's image in the public eye, therefore enhancing the company's market performance (Caesaria \& Basuki, 2017).

Reddy and Gordon (2010) conducted research on the impact of sustainability reporting on the financial performance of enterprises in New Zealand and Australia. According to the findings of the empirical investigation, sustainability reporting is statistically significant in explaining the profitability of Australian enterprises. Steyn (2014) discovered that sustainability reporting helps organizations improve their financial performance.

We also discovered other ideas that emphasize the negative aspects of non-financial reporting and firm success. In general, the financial sector appears to be less concerned with social issues than with environmental concerns (Borodin, 2019). According to the author, the company's reporting of nonfinancial information had no substantial impact on short-term or long-term financial metrics. Some academics, however, such as Cordeiro and Sarkis (1997), claim that there is a negative association between sustainability reporting and firm performance.

\subsection{Sustainable corporate finance}

Soppe (2004) recognized two characteristics when applying the notion of sustainability to finance as a discipline: first, finance is ideal to meet the "needs of future generations" due to the function of amassing money and capital, and second, the financial processes are the foundation of contemporary economic processes rather than an aim in itself, which is why financial policies must be directed toward long-term honesty and trust.

The integration of environmental, social, and governance components into financial decision-making processes is referred to as sustainable finance. Green bonds, screening, impact investments, socially responsible investments, and other financial methods and instruments are examples of this.

In today's global environment, finance plays a critical role in allocating investment to firms and sustainable projects, thereby hastening the transition to a low-carbon circular economy. Sustainable finance investigates the interactions of financial policies (funding and investment) with economic, social, and environmental challenges. Finance, in their allocation role, can assist in making strategic judgments regarding reaching sustainable goals. Furthermore, investors have the ability to influence the firms in which they invest.

A crucial advance in tackling social and environmental concerns is the transition from risk to opportunity. Investors have begun to avoid risky unsustainable organizations by investing more and more in sustainable companies and projects. As a result, investors can steer corporations toward more sustainable business practices. Both finance and sustainability are concerned with the future.

Finance promotes risk assessment and, as a result, can aid in addressing the inherent ambiguity surrounding environmental concerns such as the impact of carbon emissions on climate change. In recent decades, thinking about sustainable finance has progressed through several stages, with the emphasis steadily changing from short-term profit to long-term value creation.

\section{THE NEED FOR THE NEW PARADIGM OF SUSTAINABLE CORPORATE FINANCE}

Corporate sustainability can be considered as a new and emerging paradigm of corporate management. The term "paradigm" is used intentionally, as business sustainability offers an alternative to the typical growth and profitmaximization strategy. While corporate sustainability recognizes the importance of business growth and profitability, it also necessitates the pursuit of societal goals, notably those related to sustainable development - environmental protection, social justice and equity, and economic development. The new corporate sustainable development architecture is founded on three principles: 1 . economic integrity; 2 . social fairness; and 3. environmental integrity (van Marrewijk, 2003). These essential components, when combined, assist organizations in embracing sustainability in a way that benefits efficiency, long-term growth, and shareholder value.

Until the definition of behavioral finance, the dominant theoretical techniques linked with financial markets were those known now as traditional finance, particularly modern portfolio 
theory and the Efficient Markets Hypothesis. Traditional finance is based on the concept of "Homo Oeconomicus" (economic man), which argues that humans make economic decisions based on the principle of self-interest, the principle of rationality, and access to perfect knowledge.

Thus, classical finance is based on the principle of private ownership, which states that firms endeavor to maximize shareholder value while disregarding social and environmental factors. Because the company's purpose is limited to maximizing the process of creating cash flows, classical finance theory cannot handle the demands of financial management.

Traditional finance models are based on decision theory techniques, which begin with the premise of perfectly rational decision makers who completely grasp the decision-making scenario and who, with well-defined goals, will have no difficulty choosing solutions with the greatest utility. Traditional finance theories considered investors as logical and emotionless individuals, unaffected by prejudice or emotion, and developed models based on this premise.

Many behavioral finance theorists have rejected and criticized traditional finance theories, stating that traditional finance theories have failed to address and explain real-life problems. Olsen (1998) stated that traditional finance is insufficient since it does not account for behavioral aspects. Furthermore, as research by Kahneman and Tversky (1979), Shefrin and Statman (1994), Shiller (1995), and Shleifer (2000) has demonstrated, the rationality and maximizing the economic utility of decision makers hypothesis is impractical in real-world settings.

While accepting that decision-makers might occasionally act irrationally, have trouble analyzing the environment for decision-making, and have some confusion regarding the goals sought, behavioral finance supports the view of descriptive methods to decision theory. According to Statman (2014), individuals in traditional finance are reasonable; those in behavioral finance are normal.

Behavioral finance examines individual investors' behaviour and behavioral biases in contrast to traditional finance's completely rational investor behavior. The behavioral approach acknowledges the limits of classic finance theory and extends the models so that economic agents' conduct becomes the focus of investigation in direct relation to financial markets.

Behavioral finance focuses on financial anomalies, which are deviations from the Efficient Markets Hypothesis, namely the principle that financial markets cannot be systematically defeated.

According to research on investment behavior, investors do not have rational estimates and frequently rely on basic techniques of estimating stock prices rather than completing fundamental analyses that would disclose a company's true value.

Behavioral models, on the other hand, acknowledge the opportunism and limitations of the aspects of rationality of behaviors, but do not attribute any part of morality to economic agents. Because of the alterations of financial systems in recent decades, new techniques in finance science are required, as is a rethinking of behavioral finance.

Companies cannot be reduced to a one-dimensional financial and cash-generating body, but must be extended from a multidimensional perspective, according to the concept of sustainable finance, which includes behavioral developments while also extending the definition of economic agent to a moral human being.
The concept of sustainable corporate finance might be founded on the "moral economic man." Because of the greater utility expected in terms of the company's multidimensional objective function, the moral economic man acts logically, seeking for cooperation and confidence.

Hart and Zingales (2017) challenge the commonly held belief that externalities, such as charity, can be outsourced to the shareholder, drawing a clear distinction between shareholder value, which aims to maximize financial value, and stakeholder value, which includes social and environmental externalities. To meet varied interests, a shift to the stakeholder model necessitates new corporate governance norms and corporate investment decisions.

Another viewpoint is to broaden the corporation's purpose to optimize total or integrated value, which includes financial, social, and environmental value (Schoenmaker \& Schramade, 2020). As a result, stakeholders' current and future interests are treated equally.

\section{CONCLUSIONS}

The concept of sustainable finance has grown, with a focus on long-term strategic growth, setting the groundwork for a new financial paradigm.

In conventional finance, shareholder value is maximized by improving financial profitability and assuming the appropriate combination of risks. Although shareholder value should be regarded in the medium to long term, variables such as quarterly financial reporting and monthly / quarterly appraisal of investment performance can help to stimulate the short-term outlook. The only social obligation of a corporation is to use its resources and participate in activities that increase profits, as long as it follows the rules of the game, i.e. engages in open and free competition without deception or fraud.

In the case of sustainable corporate finance, the purpose of financial policy is sustainability, which is defined as a policy that considers future generations. Long-term financial objectives are considered in sustainable corporate finance, which reflects the company's respectable and reliable reputation. In some ways, this marks a return of social values to economic theory.

Long-term value creation considers the company's goal of optimizing long-term financial, social, and environmental value, thereby preparing for the transition to a more sustainable economic model (Dyllick \& Muff, 2016; Schoenmaker \& Schramade, 2020).

The notion of sustainable finance likewise underlines the importance of modern economic agents' behavioral premises and expressly extends the company's objectives. A company's strategy should seek for future environmental and social requirements to be the essence of the company's operation, in addition to the necessary risk / benefit objective. Corporations' responsible practices lay the groundwork for their transformation into sustainable businesses that offer value to business, society, and the environment.

Researchers and practitioners anticipate that sustainable finance will continue to evolve over the next few years, providing a method for investors to actively pursue new opportunities that standard financial analysis has failed to adequately identify or evaluate.

\section{REFERENCES}

1. Ababneh, T.A.M.; Aga, M. (2019) The Impact of Sustainable Financial Data Governance, Political 
Connections, and Creative Accounting Practices on Organizational Outcomes. Sustainability, 11, 5676.

2. Ahi, P.; Searcy, C.; Jaber, M.Y. (2018) A quantitative approach for assessing sustainability performance of corporations. Ecol. Econ., 152, 336-346.

3. Alshehhi, A.; Nobanee, H.; Khare, N. (2018) The Impact of Sustainability Practices on Corporate Financial Performance: Literature Trends and Future Research Potential, Sustainability, 10(2), 494, 10.3390/su10020494.

4. Ameer, R.; Othman, R. (2012) Sustainability Practices and Corporate Financial Performance: A Study Based on the Top Global Corporations, Journal of Business Ethics, 108(1), 61-79, 10.1007/s10551-011-1063-y.

5. Beschorner, T. (2013) Creating Shared Value: The OneTrick Pony Approach. Business Ethics Journal Review 17(1), 106-112.

6. Borodin A.; Shash, N.; Panaedova, G.; Frumina, S.; Kairbekuly, A.; Mityushina, I. (2019) The impact of the publication of non-financial statements on the financial performance of companies with the identification of intersectoral features, Entrepreneurship and sustainability issues, $\quad 7(2)$, 1666-1685, http://doi.org/10.9770/jesi.2019.7.2(61).

7. Boros A.; Fogarassy C. (2019) Relationship between Corporate Sustainability and Compliance with StateOwned Enterprises in Central-Europe: A Case Study from Hungary. Sustainability, 11(20), 5653. https://doi.org/10.3390/su11205653.

8. Caesaria A.F.; Basuki, B. (2017) The study of sustainability report disclosure aspects and their impact on the companies' performance, SHS Web of Conferences 34, 08001.

9. Carroll, A. B. (1999) Corporate social responsibility: Evolution of a definitional construct. Business and Society Review, 38(3), 268-295.

10. Clayton, T.; Radcliffe, N. (2015) Sustainability: A Systems Approach; Routledge: New York, NY, USA.

11. Cordeiro, J. J.; Sarkis, J. (1997) Environmental proactivism and firm performance: evidence from security analyst earnings forecasts. Business Strategy and the Environment, 6(2), 104-114.

12. Dey, M., Sircar, S. (2012) Integrating corporate social responsibility initiatives with business strategies: a study of some indian companies. The IUP Journal of Corporate Governance XI(1), 36-51.

13. Doz, Y., Kosonen, M. (2010) Embedding strategic agility: A leadership agenda for accelerating business model renewal. Long Range Planning 43, 370-382.

14. Dresner, S. (2012) The principles of sustainability. Routledge, New York, NY, USA.

15. Drexhage, J.; Murphy, D. (2015) Sustainable development: From Brundtland to Rio 2012. Background paper prepared for consideration by the High-Level Panel on Global Sustainability at its first meeting 19 September 2010. Adv. Appl. Sociol., 5, 12.

16. Dunphy, D. C.; Griffiths, A.; Benn, S. (2003) Organizational change for corporate sustainability: A guide for leaders and change agents of the future. Routledge: London.

17. Dyllick, T.; Hockerts, K. (2002) Beyond the business case for corporate sustainability. Business Strategy and the Environment, 11(2), 130.

18. Dyllick, T., Muff, K. (2016) Clarifying the meaning of sustainable business introducing a typology from businessas-usual to true business sustainability. Organization and Environment 29(2), 156-74.
19. Hart, O., Zingales, L. (2017) Companies Should Maximize Shareholder Welfare Not Market Value. Journal of Law, Finance, and Accounting 2(2), 247-274.

20. Hussain, N.; Rigoni, U.; Cavezzali, E. (2018) Does it pay to be sustainable? Looking inside the black box of the relationship between sustainability performance and financial performance. Corp. Soc. Responsib. Environ. Manag., 25, 1198-1211.

21. International Institute for Sustainable Development (1992) Business Strategies for Sustainable Development. Canada, Winnipeg.

22. James, M. L. (2014) The Benefits of Sustainability and Integrated Reporting: An Investigation of Accounting Majors' Perceptions. Journal of Legal, Ethical and Regulatory, 17(2), 93-113.

23. Kahneman, D., Tversky, A. (1979) Prospect theory: An analysis of decision under risk. Econometrica: Journal of the Econometric Society 47, 263-291.

24. Kates, R. W.; Clark, W. C.; Corell, R.; Hall, J. M.; Jaeger, C. C.; Lowe, I.; ... \& Faucheux, S. (2001) Sustainability science. Science, 292(5517), 641-642.

25. Lepineux, F., Rose, J.J., Bonanni, C., Hudson, S. (2010) La RSE. La responsabilité sociale de l'entreprises: Théories et pratiques. Dunod: France, Paris.

26. Linnenluecke M. K.; Griffiths A. (2010) Corporate sustainability and organizational culture. Journal of World Business, 45, 4, 357-366. https://doi.org/10.1016/j.jwb.2009.08.006.

27. Liu, J.; Mooney, H.; Hull, V.; Davis, S. J.; Gaskell, J.; Hertel, T.; ... \& Li, S. (2015) Systems integration for global sustainability. Science, 347(6225), 1258832.

28. Lopez, M V., Garcia, A., Rodriguez, L. (2007) Sustainable Development and Corporate Performance: A Study Based on the Dow Jones Sustainability Index. Journal of Business Ethics, 7, 285-300.

29. Lubin, A.D., Esty, D.C. (2010) The Sustainability Imperative. Harvard Business Review, 39-43.

30. Malovics, G., Nagypal, N.C., Kraus, S. (2008) The role of corporate social responsibility in strong sustainability. Journal of Socio-Economics 37(3), 907-918.

31. Nielsen J. (2018) Intangible Assets, Sustainability And Value Creation. Sustainability. Retrieved from https://www.sustainablebusinesstoolkit.com/intangibleassets-sustainability-and-value-creation/, accessed on 20.11.2020

32. Ngwakwe, C.C. (2008) Environmental Responsibility and Firm Performance: Evidence from Nigeria, Proceeding of World Academy of Science, Engineering, and Technology, 36 ,

33. Olsen, R. A. (1998) Behavioral finance and its implications for stock-price volatility. Financial analysts journal 54(2), 10-18.

34. Oprean-Stan, C.; Oncioiu, I.; Iuga, I.C.; Stan, S. (2020) Impact of Sustainability Reporting and Inadequate Management of ESG Factors on Corporate Performance and Sustainable Growth. Sustainability, 12, 8536. https://doi.org/10.3390/su12208536.

35. Oprean-Stan, C.; Stan, S.; Brătian, V. (2020) Corporate Sustainability and Intangible Resources Binomial: New Proposal on Intangible Resources Recognition and Evaluation. Sustainability, $12, \quad 4150$. https://doi.org/10.3390/su12104150.

36. Porter, Michael E., Kramer, Mark R. (2011) Creating Shared Value. Harvard Business Review, 62-77. 
37. Porter, Michael E., Kramer, Mark R. (2006) Strategy \& Society, the Link between Competitive Advantage and Corporate Social Responsibility, Harvard Business Review Vol. 84, Nr. 12, 78-92.

38. Rahmanti W., Hayatun A., Burhan N. (2012) The impact of sustainability reporting on company performance, Journal of Economics, Business, and Accountancy Ventura, 15(2), $257-272$.

39. Reddy K.; Lucus W. G. (2010) The Effect of Sustainability Reporting on Financial Performance: An Empirical Study Using Listed Companies, Journal of Asia Entrepreneurship and Sustainability, VI(2).

40. Salvioni, D.M.; Gennari, F.; Bosetti, L. (2016) Sustainability and convergence: The future of corporate governance systems? Sustainability, 8, 1203.

41. Schoenmaker, D., Schramade, W. (2020) Corporate Finance and Sustainability: A Teaching Note. Retrieved from http://dx.doi.org/10.2139/ssrn.3479730.

42. Shefrin, H., Statman, M. (1994) Behavioral capital asset pricing theory. Journal of financial and quantitative analysis 29(03), 323-349.

43. Shiller, R. J. (1995) Conversation, information, and herd behavior. The American Economic Review 85(2), 181-185.

44. Shleifer, A. (2000) Inefficient markets: An introduction to behavioral finance. Oxford University Press.

45. Shrivastava, P. (1995) The role of corporations in achieving ecological sustainability. Academy of Management Review, 20(4), 936-960.
46. Smigielska, G. (2018) A business case for sustainable development. Cent. Eur. Stud. (Ces) Work. Pap., 10, 49-66.

47. Soppe, A. (2004) Sustainable Corporate Finance, Journal of Business Ethics 53, 213-224.

48. Statman, M. (2014) Behavioral finance: Finance with normal people. Borsa Istanbul Review 14(2), 65-73.

49. Steyn, M. (2014) Organisational benefits and implementation challenges of mandatory integrated reporting: perspectives of senior executives at South African listed companies, Sustainability Accounting, Management and Policy Journal, 5(4), 476-503.

50. Tseng, M.-L.; Lim, M.K.; Wu, K.-J. (2018) Corporate sustainability performance improvement using an interrelationship hierarchical model approach. Bus. Strateg. Environ., 27, 1334-1346.

51. van Marrewijk, M. (2003) Concepts and definitions of CSR and corporate sustainability: between agency and communion. Journal of Business Ethics 44(2), 95-105.

52. van Marrewijk M.; Werre, M. (2003) Multiple Levels of Corporate Sustainability. Journal of Business Ethics, 44, 107-119. https://doi.org/10.1023/A:1023383229086.

53. WCED. (1987) Our common future. Oxford: Oxford University Press. 